\title{
The Effect of Cassava Peel Starch Addition to Bioplastic Biodegradation Based On Chitosan On Soil and River Water Media
}

\author{
Mahfud Syuhada ${ }^{1}$, Sintia Ainus Sofa ${ }^{2, *}$, Endaruji Sedyadi ${ }^{3}$ \\ ${ }^{1,3}$ Chemistry; ${ }^{2}$ Chemistry Education Program, Faculty of Science and Technology, UIN Sunan Kalijaga \\ J1. Marsda Adisucipto No 1 Yogyakarta 55281, Indonesia. Tel. +62-274-540971, Fax. +62-274-519739 \\ Corresponding author* \\ sintiashofa@gmail.com
}

Manuscript received: 28 November, 2019. Revision accepted: 28 February, 2020. Published: 13 April, 2020.

\begin{abstract}
The study of the relationship between starch addition to biodegradation of bioplastics has been carried out. This study aims to understand the biodegradability of chitosan-based bioplastics with additional cassava peel starch on soil and river water media. This research was conducted through four stages, namely making starch from cassava peel waste, making bioplastics using the blending and castingwet processes method with variations of starch 5, 10, 15 and $20 \mathrm{ml}$. Testing physical mechanical properties including water resistance, thickness, tensile strength, elongation, and modulus young. Testing the characteristics of bioplastics functional groups was carried out using FTIR (Fourier Transform Infrared) and biodegradation testing of bioplastics carried out on soil and river water media. The results of bioplastics research with variation $5 \mathrm{ml}$ produce good mechanical physical properties. Bioplastics produced water resistance value of $45.03 \%$, thickness of $0.0190 \mathrm{~mm}$, tensile strength of $49.93 \mathrm{MPa}$, elongation of 3.068\% and Young modulus of 1627.63 MPa. Bioplastics biodegradation test was observed by measuring the decrease in sample mass. The biodegradation test results in soil and river water media respectively showed a decrease in bioplastic mass up to $63 \%$ and $54 \%$. The biodegradation rate of the calculation results on soil media is $-0,1502$ and in river water media is $-0,0948$.
\end{abstract}

Keywords: Chitosan; Cassava Peel Starch; Bioplastic; Mechanical Properties; Biodegradation

\section{INTRODUCTION}

The annual production of petroleum based plastics (P$\mathrm{mb}$ ) was recorded more than 300 million tons in 2015 (Emadian, 2016). In the fact, $\mathrm{P}-\mathrm{mb}$ production produced above 34 million tons of water which continues to grow every year and Indonesia itself is the second largest producer of P-mb waste in the world after China (Wahyuningtyas et al., 2017). As much as $93 \%$ of the waste tends to accumulated on the surface of the land and oceans so that it was very detrimental to humans and the environment (Pathak et al., 2014). One of the efforts to save the earth from the explosion of P-mb waste is the making biodegradable bioplastics.

Biodegradable bioplastics are plastic polymers that will undergo decomposition by fungi or microorganisms. Decomposition can occur up to one hundred percent if discharged into the environment with the final result in the form of water and carbon dioxide gas without leaving a toxic residue. This bioplastic is ecofriendly, non-toxic and renewable because its constituent compounds come from plats such as starch cellulose, and lignin as well as from animals such as casein, protein and lipids (Widyaningsih et al., 2012).

One of the raw materials for making biodegradable bioplastics in this research is chitosan. Chitosan can be used as a raw material in the production of the biodegradable bioplastics due to its nature which can form clear, strong and flexible thin layers (Mackay \& Tait, 2011) non-toxic (Jara, et al., 2018). Besides that, other raw materials used in the form of cassava peel starch. Cassava peel starch is added as bioplastic material because it is believed to accelerate the biodegradation process. It happens because the ability of starch to absorb high water then becomes the optimum place for the growth of degrading microorganisms (Wahyuningtyas et al., 2017). The use of chitosan and cassava peel as an ingredient in the production of biodegradable bioplastics will increase its use value (Anita, Akbar, \& Harahap, 2013). The selection of chitosan with cassava peel as a bioplastic base is expected to be an alternative solution for making bioplastics.

Biodegradability of bioplastics in the environment has been tested through various types of experiments. It was started from using one of type of organism to complex systems such as compost and seawater (Emadian, 2016). Based on the background above, a study was conducted on the study of biodegradable plastics with raw materials in the form of chitosan with the form of chitosan with the addition of cassava peel starch in surface media and river. 


\section{MATERIALS AND METHODS}

\section{Tools and materials}

Non-electronic devices used include a set of glassware, chopsticks, tweezers, thermometers, magnetic stirrers, bioplastic molds (mica), filter paper soil testers and biodegradation media tubes. Electronic device that will be used include blenders, hot plates, ovens, and analytical tools such as analytical balances, FTIR spectrophotometers, and a set of tensile and elongation strength gauges. While the ingredients used are chitosan, cassava peel starch, $1 \%$ acetic acid and distilled water.

\section{Procedures}

- Step 1. Synthesis of Cassava Peel Starch.

Cassava peel remove the outer skin, then washed, added distilled water and blended to produce pulp. The resulting pulp is then separated between pulp and starch by filtering. Then it was deposited for several hours. The precipitate is then dried in an oven. Cassava skin starch was then analyzed using FTIR.

\section{- Step 2. Synthesis of Bioplastic}

Chitosan solution and cassava peel starch solution were taken with several variations in volume, the comparison is as follows:

- Variation 0.

Chitosan : Cassava Peel Starch (10:0) $=50: 0 \mathrm{~mL}$

- Variation 5.

Chitosan : Cassava Peel Starch $(9: 1)=45: 5 \mathrm{~mL}$

- Variation 10.

Chitosan : Cassava Peel Starch $(8: 2)=40: 10 \mathrm{~mL}$

- Variation 15.

Chitosan : Cassava Peel Starch (7:3) $=35: 15 \mathrm{~mL}$

- Variation 20.

Chitosan : Cassava Peel Starch (6:4) $=30: 20 \mathrm{~mL}$

Both solutions with each of the above comparisons were stirred for 25 minutes using a magnetic stirrer. Bioplastic solutions that have been thoroughly mixed are carefully poured into the mold. Then the printed solution is dried in an oven, then cooled to room temperature. Bioplastic that have been formed are then released for further analysis and testing.

\section{Data analysis}

\section{- Fourier Transform Infrared Spectroscopy}

Characterization of functional groups carried out by FTIR using a $\mathrm{KBr}$ pellet method. One mg of sample was mixed with $200 \mathrm{mg}$ of $\mathrm{KBr}$ powder. Samples were mixed $\mathrm{KBr}$ pellets by pressed mixture into a thin transparent using 10 tons pressure $(2000 \mathrm{psi})$. Pellet samples were then measured its infrared absorption at wavenumber 4000-400 $\mathrm{cm}^{-1}$ (Sedyadi, Anggraini, \& Ekawati, 2016).

\section{- Mechanical Properties Test}

Mechanical testing is carried out to determine thickness, tensile strength, elongation and modulus young test. Film thickness were measured using micrometer to the nearest $0.001 \mathrm{~mm}$. Thickness measurements were taken at five different points for each film sample (top right corner, bottom right corner, middle, upper left corner and the bottom left corner). Film thickness value is a average of the results of measurements at five points in units of $\mathrm{mm}$.

A set equipment test is prepared and arranged. Sample of edible film mounted at the ends of both clamping and wedged firmly. The measurement area is set with loads corresponding to pen recorder off. Tensile strength is determined by maximum load, the elongation is determined and calculated at the time the film broken. The modulus young are comparison between tensile strength and elongation.

\section{- Biodegradation Test}

Biodegradation test is carried out on two media, namely surface soil and river water. Bioplastic samples were cut $3 \times 3 \mathrm{~cm}^{2}$ in size and then weighed. The samples are stored on media in an open for 14 days. Samples are examined once every two days by means of being taken from the media, then cleaned using distilled water, dried in the oven and weighed dry mass. The mass lost from the sample is referred to as percent biodegradation which can be calculated by the equation:

Information

$$
\% \text { Biodegradation }=\frac{a 1-a 2}{a 1}
$$

$\mathrm{a} 1=$ mass before testing $(\mathrm{gram})$

$\mathrm{a} 2=$ mass after testing (gram)

\section{RESULTS AND DISCUSSION}

\section{Synthesis Cassava Peel Starch}

Cassava Peel Starch is obtained from extraction process with a smooth and abrasive surface. The total starch obtained was 26 grams from 400 gram of cassava peel waste. The process of getting cassava starch is done by making cassava peel pulp using a blender with the addition of distilled water, then the pulp is filtered and precipitated to obtain starch. The pulp filtering process is carried out in stages to produce purer starch. Distilled water are used because the nature of starch granules did not dissolve in distilled water at room temperature, so that starch can be deposited and separated easily(Kusnandar, 2010). The results of the starch are dried using an oven to reduce water content, so that it can inhibit the growth of bacteria, yeast or mold and extend the shelf life (Jabbar \& Fatimah, 2017).The dried starch is crushed to be smooth and then filtered to obtain a uniform size. 
Identification of functional groups for cassava peel starch powders have been produced from a simple extraction process is carried out using FTIR spectrophotometer at wavelength $400-4000 \mathrm{~cm}-1$. The results of FTIR analysis of cassava peel starch performed are presented in the spectra in Figure 1. Figure shows the widening absorption at the $3387 \mathrm{~cm}^{-1}$ wave number that characterizes the $-\mathrm{OH}$ group. Absorption in the area of $1026.13 \mathrm{~cm}^{-1}$ indicates the presence of $\mathrm{C}-\mathrm{O}$ groups, and absorption in the area of $2931.8 \mathrm{~cm}-1$ indicates the presence of C-H. In addition there is a peak in the wave number $1635.54 \mathrm{~cm}^{-1}$ which shows the bond that occurs cyclic or aromatic.

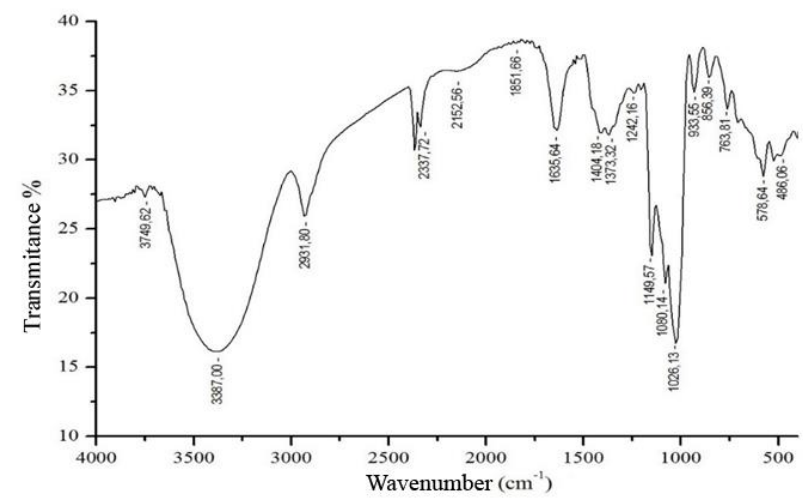

Figure 1. Spectra FTIR of cassava peel starch.

\section{Synthesis of Bioplastic}

Bioplastic were made by the blending method, which was a method that combined or mixed two or more raw materials into one. This method has advantage that the material used is relatively small, the time required is shorter and the cost is cheaper (Nurseha, 2012).

Bioplastics could be formed after going through several stages. In this research, a transparent and thin bioplastic was produced with slightly rough surface texture and a bit stiff. Chitosan is dissolved on $1 \%$ acetic acid to get chitosan solution. The use of acidic solvents was due to the nature of chitosan itself which can only dissolve in organic acids such as formic acid or lactic acid, and can dissolve completely in acidic acid. Furthermore, cassava peel starch is dissolved in distilled water and stirred using a magnetic stirrer and heated. The purpose of this warm-up is that the cassava starch and aquades can be homogenous and not separate. After the two solutions are obtained, the volume was measured according to the variations made. The two raw materials were mixed according to their variations and stirred again using magnetic stirrers until it was homogeneous. The thin layer which was referred to as bioplastic was produced thorough a wet process molding method, in which chitosan and cassava peel starch were converted into a form of solution then dried. Bioplastic thin layers could form if the cohesive attraction that occurred between molecules is adequate, sufficient diffusion and evaporation of intact water, so that the polymer chains will adjust to form layers (Kandasamy, 2005)

\section{Bioplastic Characterization}

The total content of the components used to prepare bioplastics will affect the physical and mechanical properties produced from bioplastic raw materials. The results of the physical and mechanical properties of the bioplastics carried out are shown in Table 1 as follows:

Table 1. Bioplastic characterization test results.

\begin{tabular}{cccccc}
\hline & & & Tensile & Elongation \\
$(\mathbf{\%})$ & $\begin{array}{c}\text { Modulus } \\
\text { Young } \\
(\mathbf{M P a})\end{array}$ \\
\hline $\mathbf{0}$ & 45,268 & 0,0220 & 45,7567 & 2,6549 & 1723,4811 \\
$\mathbf{5}$ & 45,034 & 0,0190 & 49,9342 & 3,0679 & 1627,6345 \\
$\mathbf{1 0}$ & 40,360 & 0,0180 & 48,4456 & 2,9836 & 1623,7297 \\
$\mathbf{1 5}$ & 36,154 & 0,0175 & 46,7011 & 2,9902 & 1561,8052 \\
$\mathbf{2 0}$ & 29,749 & 0,0755 & 9,6806 & 3,3622 & 287,9246 \\
\hline
\end{tabular}

Water resistance is an important property for bioplastic that is directly affected by the water absorption of bioplastic-forming polymers. Table 1 showed that there was a decrease in water resistance along with the addition of cassava peel starch variations. It occurred because the hydrophilic nature of starch allows for the absorption of water. The more starches were used, the lower the resistance of the bioplastics produced. Based on the results of water resistance obtained in this research, bioplastic chitosan cassava peel starch did not meet the standard criteria set by SNI. SNI set the plastic water resistance value of $99 \%$, while the bioplastics made are less than $99 \%$.

The addition of cassava peel starch would initially reduce the thickness but then increase again as the volume of starch solution variation increased. Chitosan solution in this study has physical properties that are thicker than cassava peel starch solution(Nahir, 2017), High chitosan concentration will increase the total solids in solution. So, as the volume of chitosan decreases, the total solids in the solution will decrease so the bioplastic thickness value decreases to a certain point which increase again. In addition to the volume of material solution, the bioplastic molding process on the printing plate also influences the thickness value. The bioplastic printing process is one of the crucial things that determine how bioplastics will be formed, whether thick or thin. If it is not appropriate in pouring, leveling the surface of the solution, or slope of the laying plate then the bioplastic solution will gather at one point and produce a non-uniform thickness in a single sheet of bioplastics. Chitosan bioplastic thickness with the addition of cassava peel starch variations on average under $0.25 \mathrm{~mm}$, so it can be said that some of the standard value set by JIS (Japanese Industrial Standard) of $<0.25 \mathrm{~mm}$, with the exception of variations of 20 . 
Based on Table 1, the addition cassava peel starch to chitosan bioplastics could increase the tensile strength of bioplastics. In variation 5, the tensile strength of value is the highest, then in variations 10,14 , and 20 there was a decrease in the value of bioplastics will be high if the composition of the composition was optimum, and the addition of starch could result in a decrease in tensile strength values. The optimum composition occurred in perfect balance between chitosan macromolecules and macromolecules of cassava peel starch (Nahir, 2017). If the condition of the mixed composition was only close to a little or far from the optimum condition, then with the addition of starch the value of bioplastic tensile strength would decrease because polymer bonding chain of starch would be between the chitosan polymer bonding mechanism so the interaction that occurred between the chitosan polymer chains was reduced (Saputro \& Ovita, 2017). Chitosan had a linear polymer chain so that chitosan tends to form a crystalline phase so that it can provide strength and stiffness in bioplastics(Agustin \& Padmawijaya, 2016). The results if the tensile strength of chitosan bioplastic with cassava peel starch variations have met the plastics standards set by SNI (Indonesian National Standard. In the case of variations in bioplastics 20 , with the tensile strength produced by the bioplastics only $9.6806 \mathrm{MPa}$, they cannot be said to meet the standard. This may be influenced by the inhomogeneity of the distribution of bioplastics molecules which results in a decrease in tensile strength (Utami et al., 2014).

Based on Table 1 showed that along with addition of cassava peel starch variations, the elongation valueof bioplastics is increasing. In starch there are two main constituent components, namely amylose and amylopectin chain structure is branched. This branched chain structure had an amorphous phase. When bioplastic was given a tensile load, this amorphous part was the first to experience an elongation, the amorphous phase would be attracted and stretched to form a parallel arrangement. Amorphous phase elongation process can be seen in Figure 2(Agustin \& Padmawijaya, 2016). Amylopectin was a cause of increased elongation of bioplastic chitosan-cassava peel starch. Although there was an increase in elongation, the percentage value of elongation obtained by bioplastic chitosan cassava peel starch has not fulfilled SNI of 21-220\%.

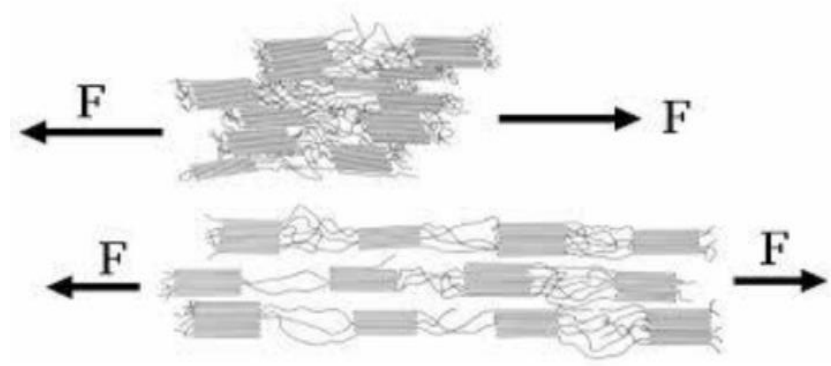

Figure 2. Bioplastic Stretch in Amorphous Phase When Given Tensile Load.
The addition of cassava peel starch variations is the cause of Young's modulus obtained by bioplastics which is decreasing. This can occur because with the addition of starch, bioplastics stiffness decreases. Bioplastic stiffness decreases due to the presence of starch branched amylopectin chains that tend to form an amorphous phase. As previously known, bioplastic stiffness is due to linear chains which tend to form crystalline phases(Agustin \& Padmawijaya, 2016). Chitosan-cassava peel starch bioplastics has two linear chains, each derived from chitosan and amylose starch. When compared with the plastic standards issued by SNI of 117.62-137.27 MPa, the Young bioplastic modulus value is far more rigid. Young modulus values for polymer-based materials range between $<10-10.000$ MPa (Hastomo, 2009).

\section{Analysis of Bioplastic Function Group}

The biodegradable bioplastic characterization that has been made was done using FTIR to determine the functional groups contained in bioplastics. The spectra of the results of FTIR analysis of chitosan and bioplastic raw materials with the best tensile strength could be seen in Figure 3.

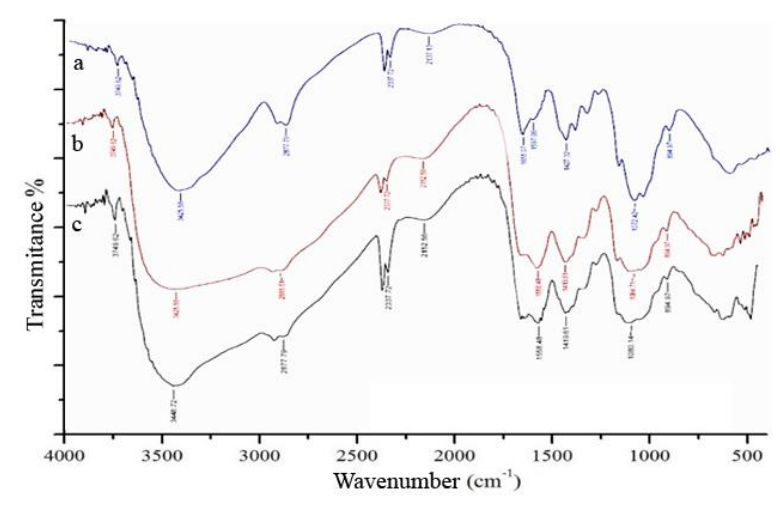

Figure 3. FTIR spectra of chitosan (a) bioplastic (b) and chitosan bioplastic with cassava peel starch (c).

Figure 3 showed that chitosan spectra have a sharp absorption with wave number $3425.58 \mathrm{~cm}-1$ indicating the presence of $\mathrm{O}-\mathrm{H}$ groups overlapping with $\mathrm{N}-\mathrm{H}$, absorption at wave number $2877.79 \mathrm{~cm}-1$ indicating the presence of $\mathrm{C}-\mathrm{H}$ and $1072.42 \mathrm{~cm}-1$ indicating the presence of C-O. After bioplastics were formed, the peak absorption pattern produced is slightly different from the basic material, namely chitosan. There was a widening strong absorption at a wavelength of 3425.58 $\mathrm{cm}-1$ indicates an $\mathrm{O}-\mathrm{H}$ group overlapping with $\mathrm{N}-\mathrm{H}$. C$\mathrm{H}$ was indicated by the absorption which was slightly shifted at wave number $2885.51 \mathrm{~cm}-1$, and for C-O it was marked by absorption at wave number $1064.71 \mathrm{~cm}$ 1. Absorption of functional groups with similar wave numbers was also produced by bioplastics chitosan 
added with cassava peel starch. In the vicinity of these wavelengths also experience widening uptake, this was due to the increase in the $\mathrm{O}-\mathrm{H}$ group due to the addition of cassava peel starch. The peak at $3448.72 \mathrm{~cm}-1$ indicates the $\mathrm{O}-\mathrm{H}$ group overlaps with $\mathrm{N}-\mathrm{H}$, the peak at wave number $2877.79 \mathrm{~cm}-1$ indicates the presence of $\mathrm{C}$ $\mathrm{H}$ and the peak at the wave number $1080.14 \mathrm{~cm}-1$ indicates the presence of $\mathrm{C}-\mathrm{O}$.

Based on the analysis of Figure 3, FTIR spectra of chitosan, chitosan bioplastics and chitosan bioplastics with addition of cassava peel starch did not show at new functional groups. This means that the bioplastic are formed come from the result of physical mixing(Saputro \& Ovita, 2017). Proposed interactions that occurred in bioplastics can be seen in Figure 4 (Afif, Wijayanti, \& Mursiti, 2018).

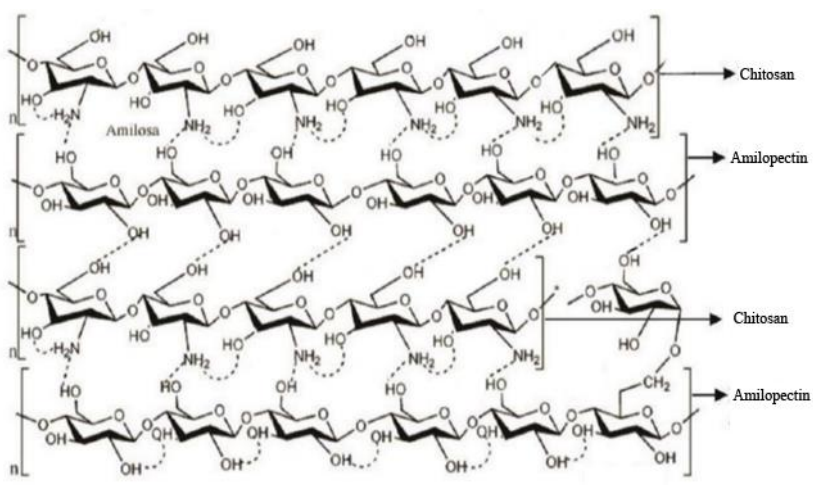

Figure 4. Proposed bioplastic interaction.

\section{Pearson Correlation Test}

The pearson correlation test results on mechanical properties presented in Table 2 can be interpreted by matching the correlation coefficient value obtained with the correlation coefficient value in Table 3.

Table 2. Pearson correlation test.

\begin{tabular}{|c|c|c|c|c|c|c|}
\hline \multicolumn{7}{|c|}{ Correlations } \\
\hline & & Variasi & Ketebalan & $\begin{array}{l}\text { Tensile } \\
\text { Strength }\end{array}$ & Elongasi & $\begin{array}{c}\text { Modulus } \\
\text { Young }\end{array}$ \\
\hline \multirow[t]{3}{*}{ Variasi } & Pearson Correlation & 1 & .660 & -698 & .838 &,- 768 \\
\hline & Sig. (2-tailed) & & 225 & 190 & .076 & 130 \\
\hline & $\mathrm{N}$ & 5 & 5 & 5 & 5 & 5 \\
\hline
\end{tabular}

It appears that the addition of cassava peel starch variation had a positive pearson correlation value of 0.669 with a significance value of 0.225 . It showed a strong relationship between the additional of cassava peel starch to thickness. Meanwhile, the pearson correlation value generated for tensile strength is negative 0.698 with a significance value of 0.190 . it showed that the addition of cassava peel starch variation has a strong negative correlation to the value of bioplastic tensile strength produced. The addition of cassava peel starch tends to reduce the value of tensile strength. pearson correlation between variation and elongation is 0.838 and has a significance of 0.076 . Based on these data it can be concluded that the addition of cassava peel starch variations has a very strong relationship to the value of the resulting bioplastic elongation. Through statistical calculations it can also be seen that the addition of cassava peel starch variation has strong relationship to Young bioplastic modulus produced with a negative value meaning that the addition of cassava peel starch tends to decrease Young's modulus value. The resulting relationship value using pearson correlation calculation is -0.768 with significance of 0.139 . Overall it can be said that the addition of cassava peel starch is strongly related to thickness and tensile strength, and is strongly related to Young's elongation and modulus.

Table 3. Level of relationship of two variables (Qudratullah, 2014).

\begin{tabular}{ll}
\hline Correlation Coefficient & Relationship Level \\
\hline 1 & Perfect \\
$0,75-0,99$ & Very strong \\
$0,50-0,74$ & Strong \\
$0,25-0,49$ & Weak \\
$0,01-0,24$ & Very Weak \\
0 & None \\
\hline
\end{tabular}

\section{Biodegradation Test}

\section{- Soil Media}

Based on the graph in figure 5, it was known that the bioplastics made have biodegradable properties, this is evidenced by the reduction in the bioplastic mass of each variation within the observation period for 14 days. The graph also showed a percent reduction in mass on one day which was equal to the increase in cassava peel starch as a variation The amorphous part of starch polymers was a less organized part compared to chitosan polymers, and enzymes from microorganisms were easier to attack and more biodegradable of less organized parts (Rohaeti, 2009). Amorphous polymers were easier to biodegrade than crystalline polymers and starch cyristallinity was lower than chitosan, so adding starch to bioplastics will further increase the rate of biodegradation(Asiah, 2010).

Percent decrease in bioplastic mass was further analyzed using analysis of variance (ANAVA) to find out whether or not there were differences resulting from each measurement of biodegradation test on the second, seventh, and fourteenth days. On the second day of the biodegradation test, the results of the analysis of variance did not show any significant difference, meaning that variations in the addition of cassava peel starch didn't significantly affect the decrease in bioplastic mass on the second day. On the seventh day of the biodegradation test, based on the analysis of variance conducted showed the same results on the second day, no significant differences occurred. This shows that the addition of cassava peel starch variation didn't produce a significant effect on the decrease in bioplastic mass on the seventh day. On the fourteenth day, the results of the analysis of variance showed a 
significant difference, which means that the addition of cassava peel starch variations resulted in a marked difference in the decrease in bioplastic mass on the fourteenth day. The results of analysis of variance in soil media can be seen that the effect of adding starch was seen to significantly occur on the fourteenth day.

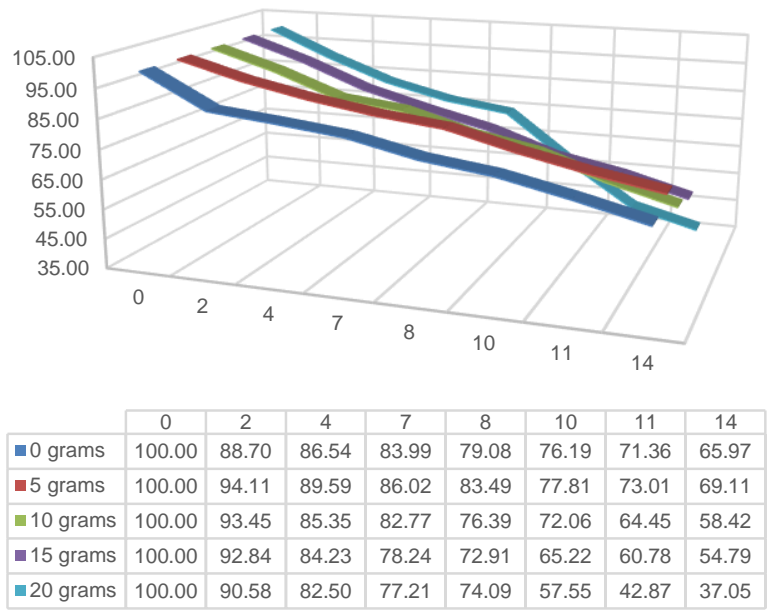

Figure 5. Graph of bioplastic biodegradation of chitosan-cassava peel starch on soil media.

\section{- River Water Media}

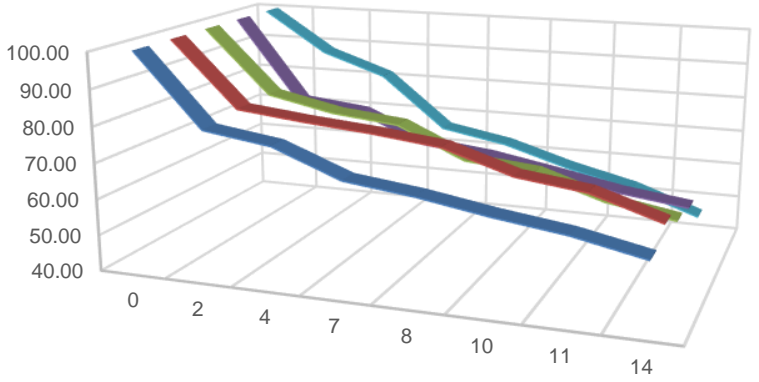

\begin{tabular}{|l|c|c|c|c|c|c|c|c|}
\cline { 2 - 9 } \multicolumn{1}{c|}{} & 0 & 2 & 4 & 7 & 8 & 10 & 11 & 14 \\
\hline - 0 grams & 100.00 & 80.08 & 77.39 & 70.07 & 67.75 & 64.55 & 61.94 & 57.97 \\
\hline -5 grams & 100.00 & 81.69 & 79.65 & 78.03 & 75.85 & 69.79 & 67.35 & 61.25 \\
\hline -10 grams & 100.00 & 81.99 & 78.05 & 76.11 & 67.57 & 65.80 & 59.67 & 56.33 \\
\hline -15 grams & 100.00 & 76.33 & 74.26 & 66.22 & 64.11 & 60.67 & 56.94 & 54.49 \\
\hline -20 grams & 100.00 & 87.98 & 81.69 & 66.70 & 63.26 & 57.57 & 53.03 & 46.31 \\
\hline
\end{tabular}

Figure 6. Graph of bioplastic biodegradation of chitosan-cassava peel starch on river water media.

Figure 6 shows that chitosan bioplastics with additional variations of cassava peel starch made have biodegradable properties, this is evidenced by the reduction in the bioplastic mass of each variation during the 14 days observation. Graph 6 showed a reduction in mass with increasing variations of cassava peel starch. In addition to the hydrophilic nature of starch which causes bioplastics to degrade more quickly, starch polymer are also favored by microorganisms which can result in the formation of large cracks and pore in bioplastic until the reduction of bioplastics mass (Alam et al., 2018).

Percent decrease in bioplastic mass was further analyzed of variance (ANAVA) to find out whether or not there were differences resulting from each measurement of biodegradation test on the second, seventh and fourteenth days. On the second day of the biodegradation test, the result of the analysis of variance showed a significant difference, meaning that variations in the addition of cassava peel starch significantly affected the bioplastic mass reduction on the second day. On the seventh day of the biodegradation test, based on the analysis of variance conducted, there was a significant difference. This shows that the addition of cassava peel starch variation produced a significant effect in the decrease in bioplastic mass on the seventh day. On the fourteenth day, the result of the analysis variance showed a significant difference, which meant that the addition cassava peel starch variation significantly affected the decrease in bioplastic mass in the fourteenth day. Data results above it was concluded that the addition cassava peel starch variation significantly affected the bioplastic mass reduction on the second, seventh and fourteenth days of biodegradation test in river water media.

\section{Comparison of Biodegradation Test}

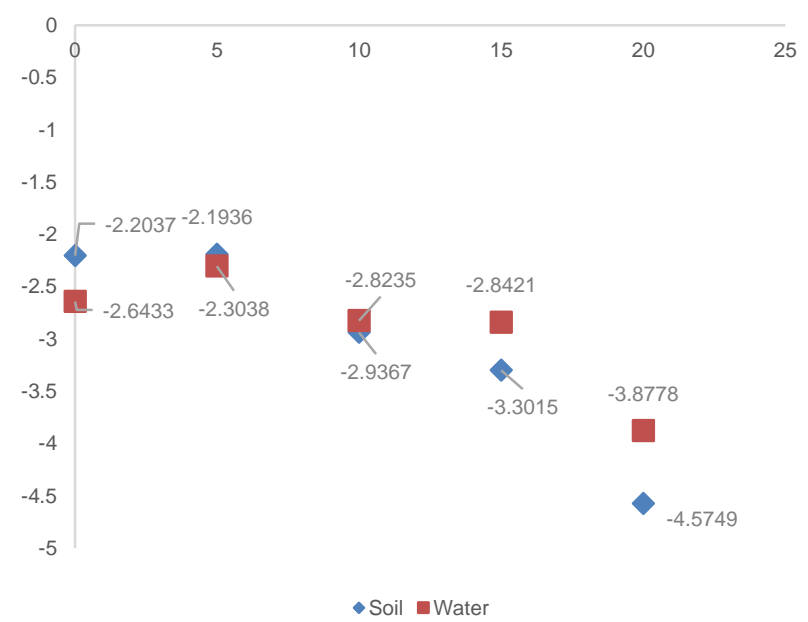

Figure 7. Graph of bioplastic mass reduction in soil and river water media.

Figure 7 showed bioplastic mass decreases more rapidly in soil media than in river water media. This is corroborated by the slope value of the biodegradation test linier equation in soil media of -0.1502 and for biodegradation test of river water media of -0.0948 . Several factors including the availability of water temperature, the amount of oxygen used, minerals, carbon $\mathrm{pH}$ and energy sources affect the growth of microorganisms in each test medium (Manika et al., 
2015). The possibility of soil media is an optimal place for growth of microorganisms becomes abundant. This causes the bioplastic biodegradation process to occur more quickly in soil media.

\section{CONCLUSION}

Based in the results obtained, it was concluded that bioplastics during biodegradability tests on both media from the first day to the fourteenth day experienced a decreases in mass. The increasing amount of starch variation, the faster biodegradation occurs. The fastest mass reduction occurs in variation 20 bioplastics, while the slowest decrease occurs in variation 5 bioplastics. If a comparison of biodegradation rates is taken in both media, the fastest biodegradation process occurs in soil media.

\section{Acknowledgements}

The author would like to thank Integrated Laboratory of UIN Sunan Kalijaga Yogyakarta for permission to conduct experiments.

\section{REFERENCES}

Afif, M., Wijayanti, N., \& Mursiti, S. (2018). Pembuatan dan Karakterisasi Bioplastik dari Pati Biji Alpukat Kitosan dengan Plasticizer Sorbitol. Indonesian Journal of Chemical Science, 7(2), 102-109.

Agustin, Y. E., \& Padmawijaya, K. S. (2016). Sintesis Bioplastik dari Kitosan Pati Kulit Pisang Kepok dengan Penambahan Zat Aditif. Teknik Kimia, 10(2), 2-16.

Alam, M. N., Nurafiani, \& Nurmalasari. (2018). Pengaruh Penambahan Pati Bonggol Pisang Terhadap Sifat Biodegradasi dari Modifikasi Plastik Propilena Menjadi Bioplastik. Dinamika, 9(1), 48-54.

Anita, Z., Akbar, F., \& Harahap, H. (2013). Pengaruh Penambahan Gliserol Terhadap Sifat Mekanik Film Plastik Biodegradarsi Dari Pati Kulit Singkong. Teknik Kimia USU, 2(2), 37-41.

Asiah, M. (2010). Uji Biodegradasi Bioplastik dari Kitosan Limbah Kulit Udang dan Pati Tapioka (Biodegradation Test of Bioplastic Based Chitosan from Shrimp Waste and Starch. Biologi Edukasi, 2(1), 13-19.

Emadian, M. S. (2016). Biodegradation of Bioplastic in Natural Environments. Waste Management, 59, 526-536.

Hastomo, B. (2009). Analisis Pengaruh Sifat Mekanik Material Terhadap Distribusi Tegangan pada Proses Deep Drawing Produk End Cup Hub Body Maker dengan Menggunakan Software Abaqus 6.5-1. Surakarta: UMS.
Jabbar, \& Fatimah, U. (2017). Pengaruh Penambahan Kitosan Terhadap Karakteristik Bioplastik dari Pati Kulit Kentang (Solanum tuberosum L.). Makassar: UIN Alauddin.

Jara, A. H., Daza, L. D., A, D. M., M, J. A., S, J. F., \& Alexander, H. (2018). Characterization of Chitosan Edible Films Obtained with Various Polymer Concentrations and Drying Temperatur. Biological Macromolecules, 113, 1233-1240.

Kandasamy, N. (2005). Development and Characterization of Antimicrobial Edible Films From Crawfish Chitosan. LSU Doctoral Disertation.

Kusnandar, F. (2010). Kimia Pangan Komponen Makro. Jakarta: Dian Rakyat.

Mackay, R. G., \& Tait, J. M. (2011). Handbook of Chitosan Research and Application. New York: Nova Science Publisher.

Manika Sharma, P. S., \& Chandra, S. (2015). Microbial Degradation of Plastic-A Brief Review. CIBTEch Journal of Microbiology, 4(1), 85-89.

Nahir, N. (2017). Pengaruh Penambahan Kitosan Terhadap Karakteristik Bioplastik dari Pati Biji Asam (Tamarindus Indica L.). Makassar: UIN Alauddin.

Nurseha, D. (2012). Pengaruh Penambahan Platicizer Sorbitol untuk Pembuatan Bioplastik dari Pati Kulit Singkong. Yogayakarta: UIN Sunan Kalijaga.

Pathak, S., Sneha, C., \& Mathew, B. (2014). Bioplastics: Its Timeline Scenario \& Challenges. Polymer and Biopolyer Phys. Chem, 2(4), 84-90.

Qudratullah, M. F. (2014). Statistika Terapan Teori, Contoh Kasus dan Aplikasi dengan SPSS. Yogyakarta: Andi.

Rohaeti, E. (2009). Karakterisasi Biodegradasi Polimer. Prosiding Seminar Nasional Penelitian, 248-257.

Saputro, A. N., \& Ovita, A. L. (2017). Sintesis dan Karakteristik Bioplastik dari Kitosan-Pati Ganyong (Canna Edulis). Kimia dan Pendidikan Kimia, 13-21.

Sedyadi, E., Anggraini, D., \& Ekawati, D. P. (2016). StrachGlycerol Based Edible Film and Effect of Rosella (Hibiscus Sabdariffa Linn) Extract and Surini Dumbo Catfish (Clarias gariepinus) Addition on Its Mechanical Properties. Biology, Medicine \& Natural Product Chemistry, 33-40.

Utami, M. R., Latifah, \& Widiarti, N. (2014). Sintesis Plastik Biodegradable dari Kulit Pisang dengan Penambahan Kitoan dan Platicizer Gliserol. Indonesian Journal of Chemical Science, 3(2), 163-167.

Wahyuningtyas, Nanang, E., \& Suryanto, H. (2017). Analysis of Biodegradation of Bioplastics Made of Cassava Starch. Mechanical Engineering Science and Technology, 1(1).

Widyaningsih, S., Kartika, D., \& Nurhayati, Y. T. (2012). Pengaruh Penambahan Sorbitol dan Kalsium Karbonat Terhadap Karakteristik Dan Sifat Biodegradasi Film Dari Pati Kulit Pisang. Molekul, 7(1), 69-81. 
THIS PAGE INTENTIONALLY LEFT BLANK 